verklaart, de benoeming aan te nemen, aan laatstgenoemde zal hiervan kennis worden gegeven ${ }^{\mathbf{1}}$ ).

Bij de rondvraag geeft de Heer Edeckoort in overweging, het Tijdschrift eens ter kennismaking te zenden aan land- en tuinbouwonderwijzers, speciaal aan die in een bepaald deel van het land, wanneer er eens een daar voorkomende ziekte in behandeld wordt. Het is hem n.l. gebleken, dat dezen het veelal niet kennen, zelfs van zijn bestaan onkundig zijn, en toch acht hij het juist ook voor hen bijzonder van belang, vooral wegens de geregeld er in voorkomende ,Aanteekeningen op plantenziektenkundig gebied". De Heer De JoNG sluit zich hierbij aan en noemt ook in 't bijzonder de hoofden der lagere landbouwscholen. De Voorzitter zal aan deze adviezen gevolg geven.

Hierop wordt de vergadering gesloten, na dankzegging aan den Heer E. D. van Dissel voor de in de lokalen van zijn bureau verleende gastvrijheid.

$\mathrm{Na}$ afloop maakten sommige aanwezigen nog gebruik van de gelegenheid om, onder deskundige leiding, het Museum van het Staatsboschbedrijf te bezichtingen ${ }^{2}$ ).

Dr. H. W. Heinsius, Secretaris.

\title{
HET GEBRUIK VAN NAPHTHALINE BIJ DEN BLOEMBOLLEN-EXPORT.
}

In de ,Annual Letter of Information No. 36", uitgegeven door de Federal Horticultural Board te Washington, wordt medegedeeld dat in het tijdperk van 1 Januari 1922 tot 31 December 1922 in 187 bloembollen-zendingen uit Nederland de aanwezigheid van vele dieren is geconstateerd.

In het kort samengevat waren dit de volgende:

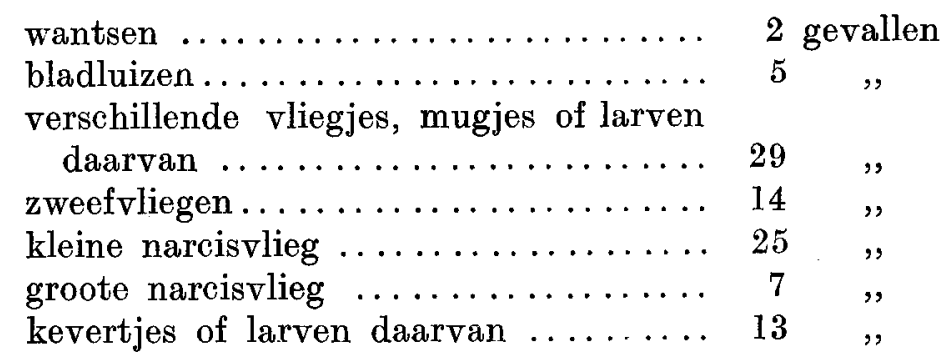

1) Inmiddels is bericht ontvangen, dat ook de Heer Vockersz de benoeming aanneemt.

2) In den jaargang 1920 van dit Tijdschrift is hiervan reeds een beschrijving gegeven. 


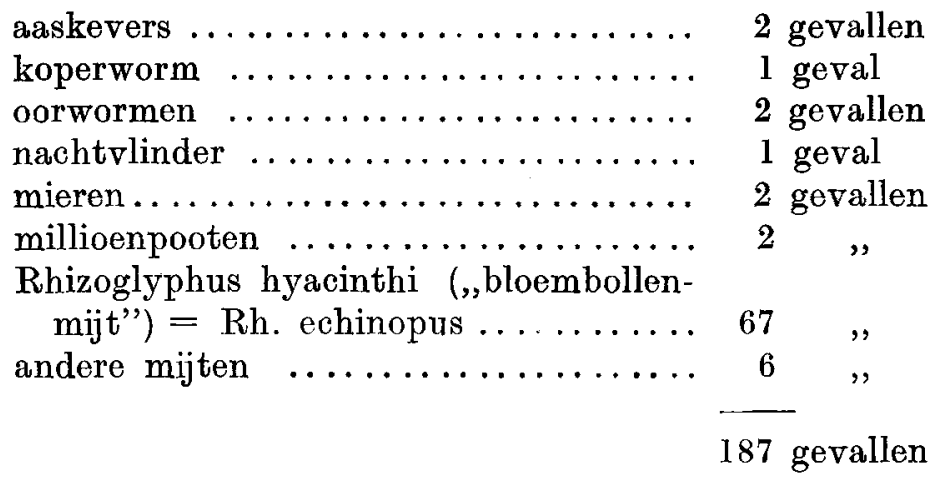

Van de genoemde dieren kan slechts de groote narcisvlieg en kunnen in zeker opzicht ook de bladluizen tot de werkelijke parasieten van bollen gerekend worden. De verdere in de lijst van den Federal Horticultural Board opgenomen diersoorten zijn voor slechts een zeer klein aantal misschien als secundaire parasieten te beschouwen, terwijl verreweg het grootste aantal soorten dezer lijst of geheel toevallig in de bloembollenzendingen aanwezig waren òf met het verpakkingsmateriaal werden ingevoerd. De laatstgenoemde twee groepen hebben stellig absoluut niets met den gezondheidstoestand der bollen te maken gehad.

In het algemeen kan men dus zeggen, dat de in 1922 naar Amerika gezonden bloembollen in zeer gunstigen toestand verkeerden.

Uit het bovenstaande lijstje schijnt te blijken, dat men in Amerika door vermelding van een groot aantal gevallen van dieren in bloembollen, de aandacht erop wil vestigen, dat onze bloembollenzendingen toch niet zoo zuiver zijn als men daar zou wenschen. In het bijzonder trekt hierbij de aandacht de vermelding van het groote aantal gevallen, waarbij Rhizoglyphus hyacinthi (Rh. echinopus) is waargenomen; nog sterker komt dit tot uiting in de opgaven der diersoorten, die in de bloembollenzendingen uit Nederland gedurende den herfst 1923 zijn waargen omen.

Deze zijn de volgende:

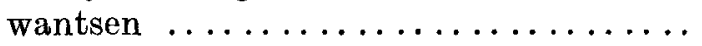

vliegjes, mugjes of larven daarvan .... 88

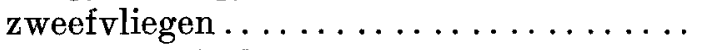

kleine narcisvljeg $\ldots \ldots \ldots \ldots \ldots \ldots$

groote narcisvlieg $\ldots \ldots \ldots \ldots \ldots \ldots, 8$

motjes, vlindertjes of larven daarvan 11 "

kevers of larven daarvan .......... 31 ",

oorwormen $\ldots \ldots \ldots \ldots \ldots \ldots \ldots \ldots, 3$,

houtluis $\ldots \ldots \ldots \ldots \ldots \ldots \ldots \ldots \ldots \ldots \ldots \ldots \ldots \ldots \ldots \ldots \ldots \ldots$ geval

springstaart $\ldots \ldots \ldots \ldots \ldots \ldots \ldots \ldots$ I , 
millioenpooten $\ldots \ldots \ldots \ldots \ldots \ldots \ldots, \quad 5$ gevallen

Rhizoglyphus hyacinthi (Rh. echinopus) 284 "

andere mijten ................ 9 ,

slakken $\ldots \ldots \ldots \ldots \ldots \ldots \ldots \ldots \ldots$........ 3 ,

diverse mij onbekende dieren ........ 9 "

472 gevallen

Het is vóór alles gewenscht, deze opgaven als waarschuwing op te vatten en tijdig aan deze aangelegenheid de noodige aandacht te wijden. De maatregelen, die hier te lande genomen worden om te voorkomen, dat door het narcissenaaltje en door de groote narcisvlieg aangetaste bollen uitgevoerd kunnen worden blijken een groot succès op te leveren. Het wordt nu echter tijd, ook aan de bollenmijten de noodige aandacht te sehenken en haar aantal in de bloembollenzendingen tot een minimum te beperken.

Naar mijn overtuiging is Rhizoglyphus hyacinthi (=echinopus) geen primaire parasiet van de blcembollen. Het is mij althans tot nog toe nooit gelukt, mijten, die ik op in rottenden toestand verkeerende bollen heb aangetroffen, op gezonde bollen in leven te houden. Het duurde in den regel niet lang of alle mijten, die op de gezonde bollen waren overgebracht, stierven.

Maar of de bollenmijt werkelijk als bollenparasiet kan optreden, is voor ons wel een zeer belangrijke, echter toch niet de belangrijkste vraag. Wij hebben immers bij den export van bloembollen naar Amerika veel meer te maken met de inzichten, die hieromtrent aldaar bestaan, dan met de onze, omdat ten slotte dáár bepaald wordt of zendingen, waarin bollenmijten voorkomen, als gevaarlijk en dus niet te aanvaarden beschouwd worden.

Daarom blijft het, in verband met de Amerikaansche opvattingen, noodig, de mijten te bestrijden, en dit kan zeer gemakkelijk geschieden met behulp van naphthalinepoeder, waarmede de bollen bestrooid worden.

Meerdere jaren geleden heb ik nagegaan of het mogelijk was, mijten, die in vochtig koolzaad optraden, op eenvoudige wijze te dooden zonder schade an het koolzaad te veroorzaken. Het is mij daarbij gebleken, dat dit zeer gemakkelijk kan geschieden door het zaad te mengen met een weinig naphthaline-poeder. Binnen korten tijd waren alle mijten gedood. Weken lang heb ik koolzaad met een overmaat van naphthaline-poeder in een gesloten glasdoos bewaard en het bleek dat de kiemkracht van het zaad niet was achteruitgegaan. 
Bij eventueele onderzoekingen van zieke bollen was het dikwijls een groot ongerief, dat de daarop aanwezige mijten zich zoo sterk vermenigvuldigden, waardoor het onderzoek bemoeilijkt werd. Dit voorkom ik thans door bij de zieke bollen een weinig naphthaline-poeder te voegen.

De reeds aanwezige mijten, hoe groot het aantal ook moge zijn en uit welke soorten zij ook bestaan, sterven spoedig en het te onderzoeken materiaal blijft er verder vrij van.

Alleen wanneer men mijten aantreft op sterk gerotte uien, zoodat de diertjes zich in de slijmerige massa bewegen, gebeurt het wel, dat enkele mijten, niettegenstaande de naphthaline, gedurende langeren tijd het leven houden.

Droogrotte bollen, waarop mijten in duizendtallen aanwezig waren, heb ik in een papieren zak gesloten met naphthaline-poeder; en het bleek, dat reeds den volgenden dag alle mijten absoluut bewegingloos waren. Naphthaline-damp is niet alleen doodelijk voor mijten doch ook voor andere dieren.

Thrips o.a. is zeer gevoelig voor naphthaline-dampen. Er deed zich n.l. een geval voor van beschadiging van leliebollen door Thrips en wel door de soort Liothrips van Eeckei Priesner.

Deze leefde tusschen de schubben der leliebollen, waardoor de planten zeer slecht groeiden. De bollen bleken niet afdoend van Thrips gezuiverd te kunnen worden door benzine- en door zwavelkoolstof-dampen, doch ik heb dit wel verkregen door de leliebollen te bestrooien met naphthaline-poeder. De eigenaar heeft daarna zijn aangetaste leliebollen dik met naphthaline-poeder bestrooid en een gedeelte daarvan gedurende 14 dagen bewaard in een met een ruit afgedekten bloempot.

Behalve dat op de bollen geen levende Thripsen meer voorkwamen bleken ze ook niet in het minst geleden te hebben.

Het zijn de bovenvermelde waarnemingen, die mij doen vermoeden, dat ook bij verzending van bloembollen, die in omstandigheden verkeeren, waarin een sterke ontwikkeling van mijten kan plaats vinden, naphthaline gebruikt zal kunnen worden om deze ontwikkeling tegen te gaan; tevens zouden daarbij ook tal van andere dieren gedood kunnen worden, o.a. zulke, die zich in het verpakkingsmateriaal bevinden. Men zou dan moeten begin aen met bollen, die eenigszins in ongunstigen toestand verkeeren, reeds op de stellingen met fijn naphthaline-poeder te bestrooien.

Verder zou dit jaar reeds proefsgewijze nagegaan kunnen worden, hoeveel naphthaline-poeder noodig is, om een bepaalde hoeveelheid bollen, die voor de ontwikkeling van mijten een gunstigen bodem opleveren, mijtrrij te houden. Dan dient nage- 
gaan te worden, hoe lang verschillende soorten van bollen verpakt kunnen blijven in een afgesloten ruimte, zonder dat dit een nadeeligen invloed uitoefent op de bollen zelf. Niet alleen is dit onderzoek noodzakelijk in verband met de verzending van bloembollen naar Amerika, doch ook bijv. met die naar Nieuw-Zeeland.

Mogelijk kunnen enkele exporteurs proefsgewijze eenige kisten bloembollen naar Amerika zenden, waarbij naphthaline-poeder tusschen de bollen wordt gestrooid.

Indien ook bij deze proefnemingen blijkt dat naphthaline-poeder afdoend is om de bollenmijt te dooden en onschadelijk is voor de bollen, dan zou het volgend jaar op grootere schaal verpakking met naphthaline-poeder kunnen plaats vinden, zoodat op deze wijze de bollen mijtvrij gehouden kunnen worden, waarbij tevens de kans zeer groot is, dat ook tal van andere dieren, die zich op en in de bollen en in het verpakkingsmateriaal mochten bevinden, eveneens gedood worden. Het zal ongetwijfeld ook zijn nut hebben, een methode te vinden, om narcisbollen, die in kierkisten verzonden worden, blootgesteld te houden aan naphthaline-dampen.

De Plantenziektenkundige Dienst is natuurlijk steeds gaarne bereid, zijne medewerking te verleenen bij het onderzoek naar de bruikbaarheid van naphthaline-poeder in de practijk, terwij1 het meer op den weg ligt van anderen, die daartoe beter in de gelegenheid zijn, na te gaan, welken invloed naphthalinedampen uitoefenen op den groei der bollen.

H. MaArschalk.

\section{MEDEDEELING VAN DE REDACTIE.}

Naar aanleiding van het artikel van den Heer J. J. Paereus over de voornaamste ziekten en plagen van den Cacaoboom op Java, opgenomen in den loopenden jaargang van het ,Tijdschrift over Plantenziekten", 3e afl., blz 51-61, deelde de Heer Dr. F. W. T. HuNGer te Amsterdam ons mee, dat dit artikel, zonder vermelding van de bron, geheel, hier en daar zelfs bijkans woordelijk, ontleend is aan diens Caca-aruikel in VAN Gorkom's „,Oost-Indische Cultures”, 2e druk, deel II, blz. 542—567 (1918). Zulks was ons, tot onzen spijt, ontgaan. Thans zijn wij in de gelegenheid geweest, ons te overtuigen van de juistheid van hetgeen ons door Dr. Hunater werd geschreven. Hadden wij er eerder kennis van gedragen, dat het artikel van de Heer Pakress niet veel anders was dan eene weergave van een gedeelte van het werk van DR. Hunger, dan hadden wij het bedoelde artikel niet in het Tijdschrift opgenomen, althans zeker niet als oorspronkelijk stuk.

De Redactie. 